\title{
Peripheral Blood Lymphocyte Cell Surface Markers during the Course of Systemic Lupus Erythematosus
}

\author{
Ronald P. Messner, Folke D. Lindström, and Ralph C. Williams, Jr. \\ From the Arthritis Unit, Department of Medicine, Bernalillo County Medical \\ Center, University of New Mexico School of Medicine, \\ Albuquerque, New Mexico 87131
}

\begin{abstract}
A B S T R A C T Peripheral blood lymphocytes from 23 patients with active systemic lupus erythematosus (SLE) were serially studied. Changes in bone marrow-derived lymphocytes (B cells), as measured by surface Ig receptors and $\mathrm{C} 3$ receptors, and in thymus-derived cells ( $\mathrm{T}$ cells) measured by rabbit $T$-cell-specific antiserum and E-binding techniques, were correlated with fluctuations in clinical disease activity and treatment. In normal controls $\mathrm{B}$ - and $\mathrm{T}$-cell percentages remained relatively stable, although the situation in SLE was much more labile. A relative and absolute decrease in $\mathrm{T}$ lymphocytes and cells bearing a receptor for $\mathrm{C} 3$ was found in active lupus. Absolute numbers of cells bearing surface Ig were decreased to a lesser extent, whereas the proportion of these cells was increased. It is postulated that the increase in autoantibody formation and diminished de layed hypersensitivity seen in systemic lupus may be due to a loss of T-lymphocyte function.
\end{abstract}

\section{INTRODUCTION}

A growing body of evidence can now be marshalled to support the concept that lymphocytes play a fundamental role in the pathogenesis of connective tissue disorders such as rheumatoid arthritis (RA) ${ }^{1}$ or systemic lupus erythematosus (SLE). Lymphocytes can be divided into two basic groups: bone marrow-derived B cells which bear readily detectable surface immunoglobulin ( $\mathrm{Ig}$ ) and apparently are the principal effector cells of antibody formation and humoral immunity (1-6); and T cells or thymus-derived cells that show no easily detectable surface Ig and are the principal mediators of cellular im-

Received for publication 3 May 1973 and in revised form 23 July 1973.

${ }^{1}$ Abbreviations used in this paper: B cells, bone marrowderived lymphocytes; CLL, chronic lymphatic leukemia; RA, rheumatoid arthritis; SLE, systemic lupus erythematosus; $\mathrm{T}$ cells, thymus-derived lymphocytes. munity (7-11). Previous studies from several laboratories (12-16) have indicated the presence of lymphocytotoxic antibodies among patients with connective tissue diseases particularly individuals with SLE. We have observed that cytotoxic antibodies in sera of patients with SLE have relative specificity for T cells (17). Mellors, Shirai, Toshikazo, and Yashiki $(18,19)$ have recorded the presence of similar thymocyte-specific lymphocytotoxic antibodies in New Zealand Black (NZB) mice. In addition, certain patients with active RA show what appears to be a decreased proportion of peripheral blood $T$ cells and an increase in the fraction of null cells, that is cells that cannot readily be classified as $T$ cells or B cells using immunofluorescent techniques (20, 21). Again similar findings have been recorded $(22,23)$ during the development of the naturally evolving lupus-like syndrome in NZB mice.

Besides surface Ig markers characteristic of $B$ cells and the so-called $\theta$-marker associated with $\mathrm{T}$ cells $(7,8)$, two other markers have been described that may be important in evaluating subtle alterations in lymphocytes. $B$ cells bear surface receptors for the third component of complement (C3) in addition to their Ig receptor molecules $(24,25)$ whereas $T$ cells form rosettes with unsensitized sheep erythrocytes (26-38). The present work reports a sequential study of peripheral blood lymphocytes among patients with SLE with particular emphasis on changes in $\mathrm{T}$ - to $\mathrm{B}$-cell ratios as correlated with fluctuations in clinical disease activity. Two markers were used to determine both types of lymphocytes.

\section{METHODS}

Patients studied. Serial studies were performed in 23 SLE patients followed in the lupus clinic at Bernalillo County Medical Center. These patients had been diagnosed as active SLE on the basis of strongly positive LE preps plus characteristic multisystem involvement using criteria recently established by the American Rheumatism Association (29). Single observations were made in an 
additional six patients. Many patients were receiving corticoids and/or azathioprine during the course of study but several individuals were studied before any such therapy had been instituted. Absolute lymphocyte counts were calculated from the total leukocyte count and percent lymphocytes on differential count.

Special studies. Heparinized blood samples were allowed to sediment by gravity for $1 \mathrm{~h}$ and fresh human lymphocytes separated by Hypaque-Ficoll gradient as previously described $(25,30)$. B cells were enumerated using direct immunofluorescence and fluorescein-conjugated antiIg antibodies isolated and purified as previously described from immunoabsorbent columns $(1,4,25)$. Cells were stained for surface $\operatorname{IgG}, \operatorname{Ig} A, \operatorname{Ig} M$, and in some instances for IgD. The sum of cells staining for IgG plus IgA plus IgM was generally taken as the percent $B$ cells since previous work $(21,25,31)$ using anti- $\mathrm{F}(\mathrm{ab})_{2}{ }^{\prime}$ fluorescent reagents had indicated most cells bear one major Ig class of surface immunoglobulin. In some instances double labeling of lymphocytes with rhodamine-conjugated anti-IgG and FITC-conjugated anti-IgA or anti-IgM was done to determine to what extent more than one class of immuno globulin might occur on the lymphocyte surface. B-cell C3 receptors were enumerated (25) using sheep cells sensitized with antibody and the first four components of human complement (EAC3).

$\mathrm{T}$ cells in peripheral blood lymphocyte preparations were detected using two parallel methods. The technique of indirect immunofluorescence previously described (20, 21) used several rabbit antisera prepared against pooled human fetal thymocytes. Such antisera were absorbed with cells from several patients with chronic lymphatic leukemia (CLL) used as a source of $B$ cells $(4,21)$. These absorbed antisera showed no specificity for particular HL-A antigens but did show anti-T-cell reactivity. In addition, some rabbit antisera prepared against human thoracic duct lymphocytes ${ }^{2}$ and similarly absorbed with CLL lymphocytes showed very similar staining specificity and could also be used as $T$-cell reagents in the indirect immunofluorescent procedure.

A second method of enumerating $T$ cells utilized the E-binding sheep cell rosette method as outlined by Fröland (26) and several other groups $(27,28)$. It was necessary to confirm the fact that the cells measured by indirect immunofluorescence and those identified as $T$ cells by $E$ binding were indeed the same population of cells. In experiments where both methods were used simultaneously, it appeared that $\mathrm{E}$ binding and fluorescence identified the same population of cells, however, rosette formation often obscured fluorescence. For this reason, additional experiments were done in which a relatively pure population of $T$ cells was obtained by differential centrifugation of $B$ cells, utilizing EAC3 rosettes. Representative results shown in Table I demonstrated that the percentage of $T$ cells by immunofluorescence and $\mathrm{E}$ binding was equally enriched when the majority of $B$ cells were removed using this procedure.

Finally a panel of eight SLE sera was selected for use as reagents to examine possible subtle cell surface changes during the course of systemic lupus. These sera were chosen from a large group of lupus sera previously studied $(16,17)$ and consisted of four sera showing broad cytotoxicity in the microcytotoxicity technique described by

${ }^{2}$ Human thoracic duct lymphocytes were provided by Doctors J. Peter and C. Pearson, UCLA Medical Center from patients with RA undergoing thoracic duct drainage.
TABLE I

Differential Centrifugation on Ficoll to Eliminate B Cells Utilizing EAC3 Rosettes*

\begin{tabular}{lccc}
\hline & $\begin{array}{c}\text { B cells, } \\
\text { percentage }\end{array}$ & $\begin{array}{c}\text { T cells, } \\
\text { percentage }\end{array}$ & $\begin{array}{c}\text { E-binding } \\
\text { cells, } \\
\text { percentage }\end{array}$ \\
\hline $\begin{array}{l}\text { Normal lymphocytes } \\
\text { separated on Ficoll }\end{array}$ & 18 & 80 & 62 \\
$\begin{array}{l}\text { After separation of } \\
\text { B cells using } \\
\text { centrifugation of } \\
\text { EAC3 rosettes }\end{array}$ & 5 & 93 & 75 \\
\hline
\end{tabular}

* Relatively pure T-cell population in top layer has been identified with $\mathrm{T}$-cell-specific antiserum and E-binding technique.

Terasaki and McClelland (32) as well as four SLE sera with low or absent cytotoxicity. The four strongly cytotoxic sera had shown apparent $\mathrm{T}$-cell specificity in our previous studies (17). It was felt these sera might detect serial changes in lymphocytes from patients possibly not demonstrable in the other test systems outlined above. The lymphocytotoxic activity of sera drawn from the patient under study was determined using the same microcytotoxicity technique with three lymphocyte panels: $(a)$ normal, composed of lymphocytes from 15 normal donors; $(b)$ thymic, composed of cells from the thymuses of two stillborn fetuses and thoracic duct cells from two RA patients, and (c) CLL, composed of cells from four patients with CLL. Killing of less than $20 \%$ of cells was considered a negative test. When comparing cytotoxicity of SLE sera with disease activity, the cytotoxic index was defined as the mean percentage of cells of each donor-cell panel killed by the serum.

\section{RESULTS}

The mean percent of lymphocytes identified as $T$ cells with anti-T-cell serum in 83 normal individuals on the basis of 130 observations was $79.6 \%$ (Table II). This was significantly higher than the $67.4 \%$ recorded in 29 patients with SLE. Although the normal mean values for $\mathrm{E}$ binding were lower than those obtained with anti$\mathrm{T}$-cell serum, the difference between patients and controls was nearly the same, 53.8 vs. $64.8 \%$, respectively. In contrast to the data on $\mathrm{T}$ lymphocytes, the two methods used to identify $B$ lymphocytes did not agree. The percent of lymphocytes identified as $B$ cells by the sum of cells reacting with anti-IgG, IgA, and $\operatorname{IgM}$ in $98 \mathrm{ob}$ servations in 29 patients with SLE was increased, $26.5 \%$ compared with $21.9 \%$ in controls. On the other hand, the percent of lymphocytes identified as B cells by the EAC3 rosette technique was significantly decreased in SLE, 11.8 vs. $15.9 \%$ in normal individuals. Similar data on the absolute number of $\mathrm{T}$ and $\mathrm{B}$ cells is also shown in Table II. Significant decreases were found in the $a b-$ solute number of cells identified by anti-T-cell sera, $\mathrm{E}$ binding, and EAC3 rosettes. The absolute number of 


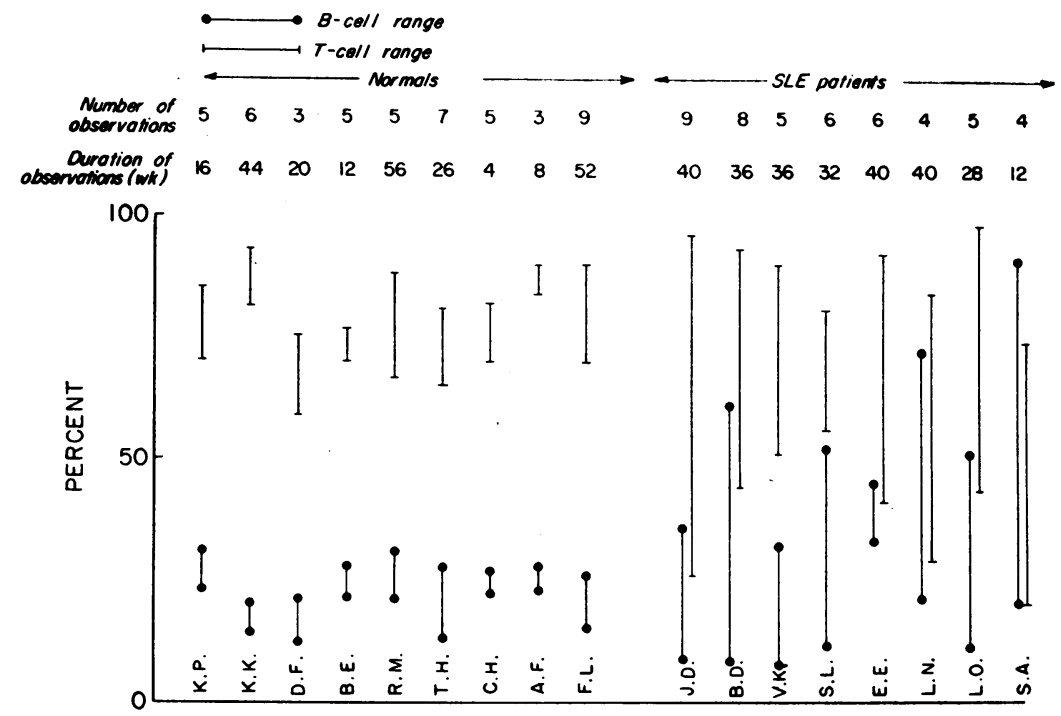

Figure 1 Range of values for percent of lymphocytes identified as $\mathrm{T}$ cells by anti-T-cell serum, and $\mathrm{B}$ cells by anti-immunoglobulin sera in nine representative normal individuals and eight patients with SLE.

cells with detectable surface Ig was also significantly decreased, but the difference from normal was not as great as with the other three lymphocyte markers.

In an attempt to correlate the percent of $\mathrm{T}$ and $\mathrm{B}$ lymphocytes in the peripheral blood with disease activity and/or treatment, serial determinations were performed on 23 patients over a 3-15 mo period. 12 normal individuals were also studied serially to provide control data on the stability of the four lymphocyte markers. Fig. 1 illustrates representative data on nine normal individuals and eight patients. It can be seen that only minor fluctuations occurred in the percent of $\mathrm{T}$ and $\mathrm{B}$ cells determined by immunofluorescent techniques in normal controls whereas the range of values on individual patients was much greater. The stability of normal values illustrated in Fig. 1 is also demonstrated on a statistical basis in Table III. Standard deviation within serially studied normal individuals for $\mathrm{E}$ binding, and $\mathrm{B}$ cells by anti-Ig sera or EAC3 rosettes was less than $5 \%$. A somewhat larger deviation of $13.3 \%$ was recorded for the percent of lymphocytes reactive with anti-T-cell serum within normal individuals. The standard deviation

TABLE II

Comparison of $T$ and B Cells in Patients with SLE and Normal Controls

\begin{tabular}{|c|c|c|c|c|c|c|c|c|c|c|}
\hline & \multicolumn{5}{|c|}{ Percent lymphocytes } & \multicolumn{5}{|c|}{ Absolute numbers of lymphocytes } \\
\hline & $\begin{array}{l}\text { Number } \\
\text { of indi- } \\
\text { viduals }\end{array}$ & $\begin{array}{c}\text { Number } \\
\text { of obser- } \\
\text { vations }\end{array}$ & Mean* & SD & $P$ & $\begin{array}{l}\text { Number } \\
\text { of indi- } \\
\text { viduals }\end{array}$ & $\begin{array}{l}\text { Number } \\
\text { of obser- } \\
\text { vations }\end{array}$ & Mean* & SD & $P$ \\
\hline \multicolumn{11}{|l|}{$\mathbf{T}$ cells } \\
\hline \multicolumn{11}{|l|}{$\begin{array}{c}\text { Anti-T cell } \\
\text { Serum }\end{array}$} \\
\hline Normal & 8.3 & 1.30 & 79.6 & 14.4 & \multirow{2}{*}{$<0.001$} & 83 & 130 & 1730.5 & 313.1 & \multirow{2}{*}{$<0.001$} \\
\hline SLE & 29 & 99 & 67.4 & 13.2 & & 24 & 68 & 1044.5 & 531.9 & \\
\hline \multicolumn{11}{|l|}{ E binding } \\
\hline Normal & 46 & 7.3 & 64.8 & 13.6 & \multirow{2}{*}{$<0.005$} & 46 & 7.3 & 1408.8 & 295.7 & \multirow{2}{*}{$<0.001$} \\
\hline SLE & 26 & 72 & 5.8 & 12.5 & & 19 & 48 & 791.5 & 47.3 .8 & \\
\hline \multicolumn{11}{|c|}{ B cells } \\
\hline \multicolumn{11}{|c|}{ Anti-Ig Sera } \\
\hline Normal & 83 & 132 & 21.9 & 6.7 & \multirow{2}{*}{$<0.01$} & 83 & 1,32 & 476.1 & 145.7 & \multirow{2}{*}{$<0.025$} \\
\hline SLE & 29 & 98 & 26.5 & 10.8 & & 24 & 68 & 386.8 & 223.9 & \\
\hline \multicolumn{11}{|c|}{ EAC 3 rosettes } \\
\hline Normal & 36 & 69 & 15.9 & 2.4 & \multirow{2}{*}{$<0.001$} & 36 & 98 & 344.8 & 52.2 & \multirow{2}{*}{$<0.001$} \\
\hline SLE & 24 & 60 & 11.8 & 4.2 & & 19 & 44 & 165.3 & 82.8 & \\
\hline
\end{tabular}

* Calculated using mean for individuals where multiple determinations were available on that individual. 

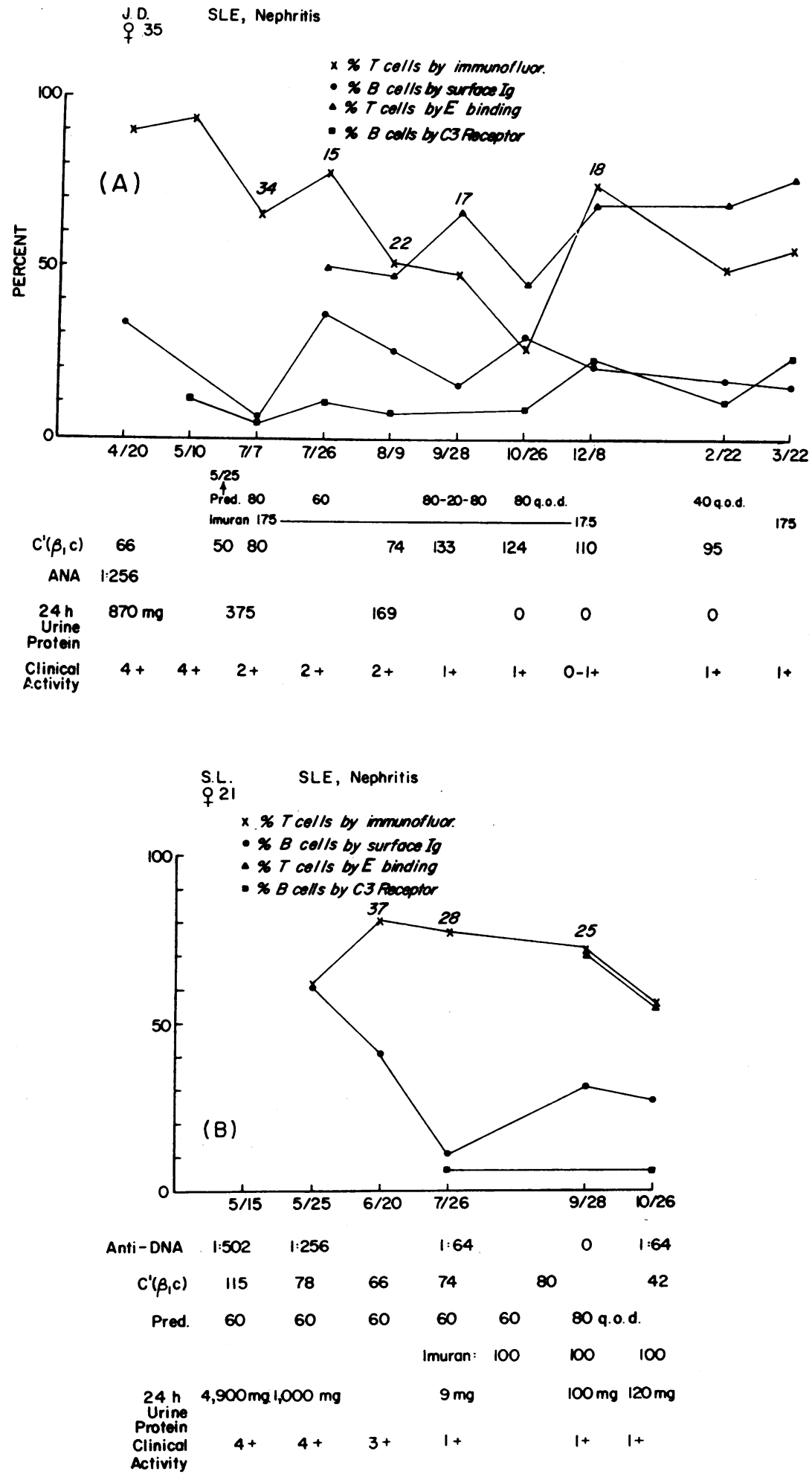

Figure 2 Serial determinations of $\mathrm{T}$ and $\mathrm{B}$ lymphocytes, laboratory data, and clinical status of two young women with acute lupus nephritis. Numbers in italics above the percent $T$ cells by immunofluorescence indicate the cytotoxic index of the serum. 

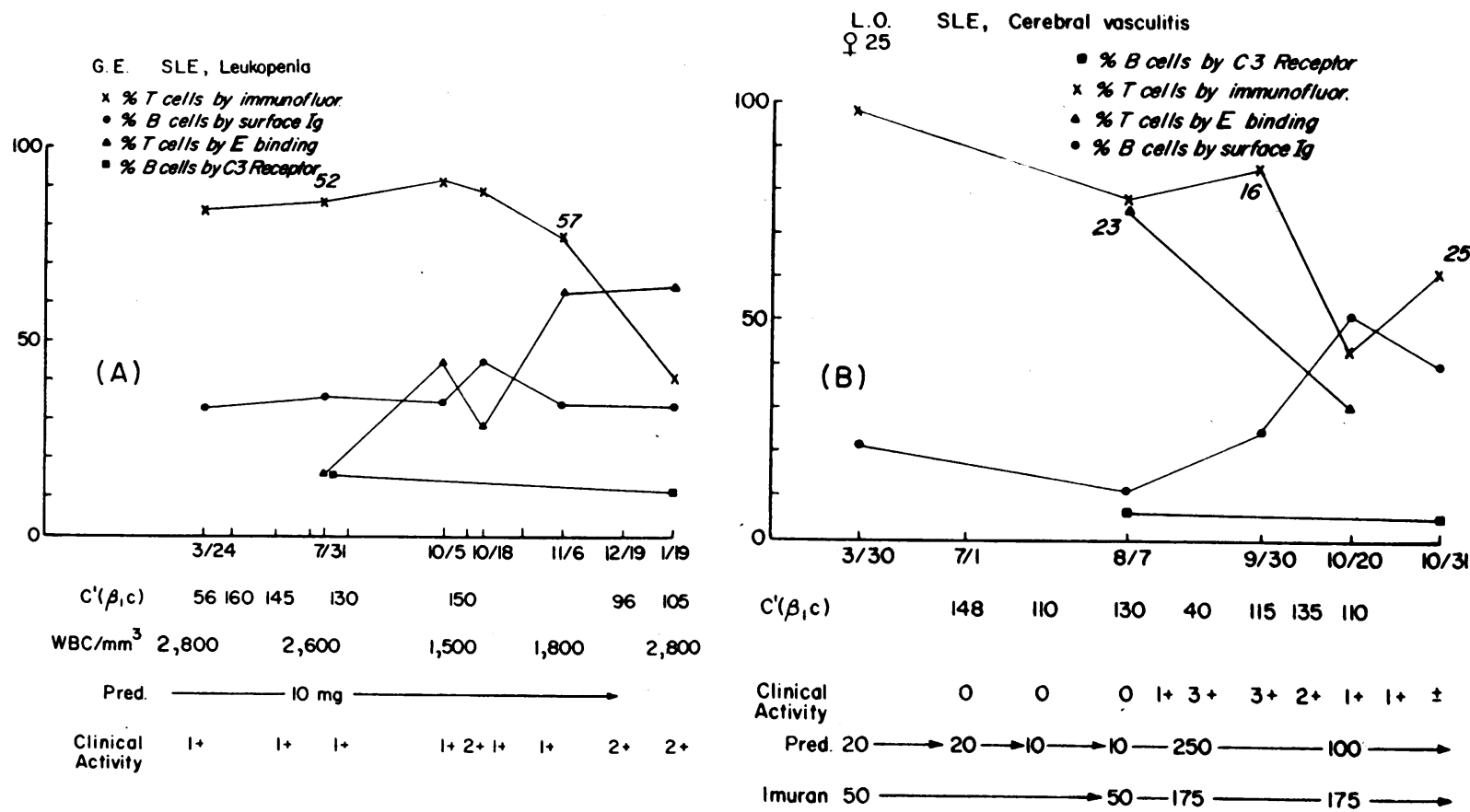

Figure 3 Serial determinations of $\mathrm{T}$ and $\mathrm{B}$ cells, laboratory data, clinical status, and cytotoxic index (italics) in two patients observed during an exacerbation of disease activity.

of values within individual patients with SLE was significantly greater than that of normal controls with all four techniques.

Serial observations on two patients with active lupus nephritis are shown in Fig. 2. Early in her course J. D. (Fig. 2A) showed relatively high percentages of $\mathrm{T}$ cells as measured by anti-T-cell sera; after institution of prednisone and azathioprine therapy, there was a progressive fall in percent of peripheral blood $T$ cells as measured by the immunofluorescent technique to a low value of $26 \%$, rebounding 2 mo later to $75 \%$. This was associated with a gradual and sustained rise in serum complement $\left(\beta_{1} \mathrm{C}\right)$ levels and clinical improvement marked by virtual disappearance of proteinuria. During this time relative proportions of $\mathrm{B}$ cells by the immunofluorescent method varied from 6 to $46 \%$. Marked discrepancies were noted between the proportion of $\mathrm{B}$ cells

TABLE III

Standard Deviation of Percent Values within Serially Studied Single Individuals

\begin{tabular}{lrrl}
\hline & Normal & SLE & \multicolumn{1}{c}{$P$} \\
\hline Anti-T-cell sera & 13.3 & 19.1 & $<0.02$ \\
E binding & 4.9 & 16.5 & $<0.001$ \\
Anti-Ig sera & 1.9 & 14.3 & $<0.001$ \\
EAC3 rosettes & 2.5 & 5.2 & $<0.001$ \\
\hline
\end{tabular}

identified by sum of cells showing surface $\operatorname{IgG}+\operatorname{IgA}+$ $\mathrm{IgM}$ and those enumerated through the $\mathrm{C} 3$ receptor method. These discrepancies were considerably more than was generally seen among normal subjects. $\mathrm{T}$ lymphocytes as measured by $\mathrm{E}$ binding also varied considerably and appeared to have a rough correspondence to values for $T$ cells determined by anti-T-cell sera. S. L. (Fig. 2B) on the other hand showed relatively high values for B cells (62 and later $40 \%$ ) when first seen. Later as she was felt clinically to be improving, the percent of $B$ cells as identified by the sum of cells reacting with the three anti-Ig sera became lower and varied from 5 to $30 \%$. A slight fall in T-cell values from 78 to $56 \%$ was noted after institution of azathioprine therapy.

Dramatic changes in the percent of cells identified as $\mathrm{T}$ and $\mathrm{B}$ lymphocytes by immunofluorescent techniques are also demonstrated in the two patients illustrated in Fig. 3. G. E. (Fig. 3A) is an individual whose main manifestations of SLE have been diffuse myalgias and a persistent granulocytopenia. This has been associated with an elevation of both percent and absolute numbers of lymphocytes bearing surface Ig in peripheral blood. It can be seen that a marked fall in the percent $T$ cells occurred in association with an increase in disease activity probably beginning on 8 October 1972. The proportions of E-binding $\mathrm{T}$ cells have increased during the last $5 \mathrm{mo}$. In this patient, the percentage of lymphocytes reacting with EAC3 was again noted to be less than that 
reacting with the three anti-Ig sera. Whereas the drop in percent $T$ cells in patient $G$. E. occurred while she was receiving a stable low dose of prednisone, the decrease in percent $\mathrm{T}$ cells noted in patient L. O. (Fig. 3B) occurred after the dosage of prednisone and azathioprine had been greatly increased in an attempt to control an exacerbation of cerebral vasculitis. In this situation, a corresponding rise in the percent of cells bearing surface Ig occurred. A similar rise in percent B cells accompanying a fall in $T$ cells was noted in two other patients after exacerbation of disease activity and institution of high dose prednisone and azathioprine treatment.

To determine the overall pattern of $\mathrm{T}$ - and $\mathrm{B}$-cell changes during different types of clinical courses, SLE patients whose long-term (3-15 mo) serial studies had been completed were divided into three categories: $(a)$ definite exacerbations of disease; $(b)$ steady improvement; and $(c)$ essentially stable course. Of the seven patients who experienced an exacerbation of disease activity while under observation, the percent of lymphocytes identified as $T$ cells by anti-T-cell serum decreased in six and that of B cells by anti-Ig sera rose in six ( $\mathrm{Ta}$ ble IV). 11 patients were observed while undergoing improvement. Nine of these showed a decrease or no change in the percent of B-cells. Approximately equal members demonstrated increasing and decreasing percentages of $\mathrm{T}$ cells. Eight patients were observed during periods when their disease was stable. In this group the percent of $\mathrm{B}$ cells by immunofluorescence showed no change and $\mathrm{T}$ cells also appeared more stable. One patient in each of the latter two groups had violent fluctuations in the percent of $T$ and $B$ cells. These changes had no obvious correlation with the otherwise steady improvement in one and stable course in the other patient. They could not be classified according to change in lymphocytes and remain an enigma. Analysis of these data using Fisher's exact probability test revealed a significant correlation $(P<0.01)$ between changes in percent of $B$ cells and changes in disease activity. No significant correlation was found with change in percent $T$ cells.

Since the majority of patients with exacerbations of disease were promptly treated with corticoid and azathioprine, the preceding data based on clinical activity include the effects of therapy. A rapid fall in percent $T$ cells accompanied by rise in B-cell proportion was however seen in one SLE patient receiving no immunosuppressive drugs and who was observed during the development of an acute exacerbation of multisystem disease. This patient is illustrated in Fig. 4 (L. N.). These data are important since they indicate that rapid changes in proportions of peripheral blood $\mathrm{T}$ and $\mathrm{B}$ cells can occur in absence of corticoid or azathioprine therapy. In addition, a total of seven patients were studied while acutely ill

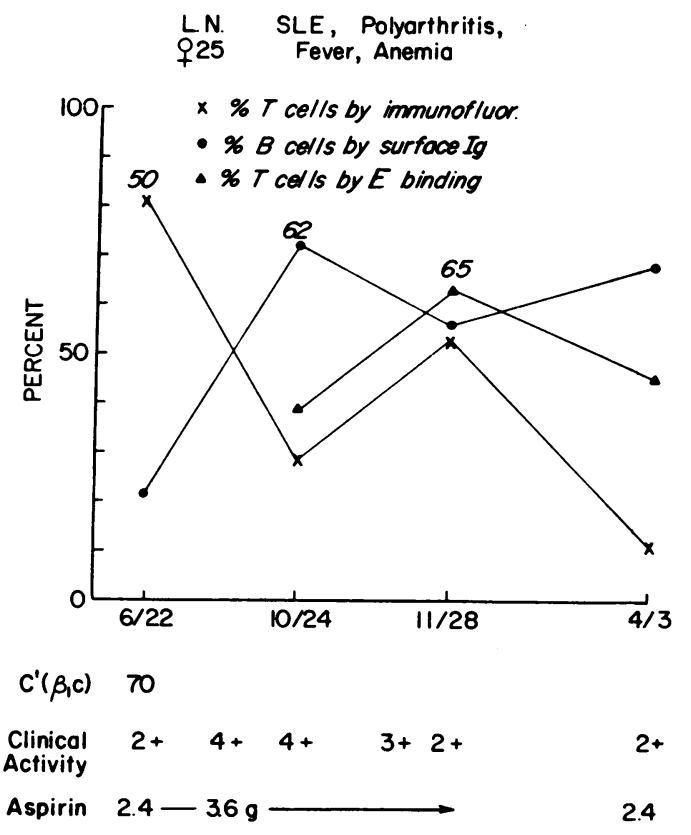

FIgURE 4 Serial determinations of $\mathrm{T}$ and $\mathrm{B}$ cells, laboratory data, clinical status, and cytotoxic index (italics) on one patient receiving only aspirin during an exacerbation of disease activity.

and before the institution of any therapy. These data together with those on patient L. N., during the exacerbation of her disease while on aspirin alone, are presented in Table V. It can be seen that compared with normal controls, six of these eight patients had increases in the percentage of cells measured by surface Ig but the percent of $T$ cells was decreased in four. The mean values for these eight patients follow the same pattern as those for the entire group of 29 shown in Table II. In terms of absolute numbers of circulating lymphocytes, while both $\mathrm{T}$ and $\mathrm{B}$ cells were reduced below normai values, the re-

TABLE IV

Changes in Percent of Lymphocytes Identified as $T$ or $B$ Cells by Immunofluorescent Techniques Compared with Changes in Disease Activity

\begin{tabular}{|c|c|c|c|c|c|c|}
\hline \multirow{3}{*}{$\begin{array}{l}\text { Change in \% } \\
\text { lymphocytes }\end{array}$} & \multicolumn{6}{|c|}{ Number of patients } \\
\hline & \multicolumn{2}{|c|}{ Exacerbation } & \multicolumn{2}{|c|}{ Improvement } & \multicolumn{2}{|c|}{ Stable } \\
\hline & $\mathrm{T}$ & B & $\mathrm{T}$ & B & $\mathrm{T}$ & B \\
\hline Increase & 1 & 6 & 4 & 1 & 2 & 0 \\
\hline No change & 0 & 1 & 1 & 4 & 4 & 7 \\
\hline Decrease & 6 & 0 & 5 & 5 & 1 & 0 \\
\hline Total & \multicolumn{2}{|c|}{7} & \multicolumn{2}{|c|}{$11^{*}$} & \multicolumn{2}{|c|}{$8^{*}$} \\
\hline
\end{tabular}

* Unexplained violent fluctuations in percent $\mathrm{T}$ and $\mathrm{B}$ cells in one patient. 
TABLE V

Percentages and Absolute Members of $T$ and B Lymphocytes in Acutely Ill Patients not Receiving Corticoid or Azathioprine Treatment

\begin{tabular}{|c|c|c|c|c|}
\hline \multirow[b]{2}{*}{ Patient } & \multicolumn{2}{|c|}{$\begin{array}{l}\text { Determined by } \\
\text { Anti-Ig sera }\end{array}$} & \multicolumn{2}{|c|}{$\begin{array}{l}\text { Determined by } \\
\text { Anti-T-cell serum }\end{array}$} \\
\hline & Percent & Absolute & Percent & Absolute \\
\hline A. $R$. & 45 & 210 & 81 & 379 \\
\hline J. D. & 33 & 487 & 80 & 999 \\
\hline S. A. & 29 & 183 & 72 & 453 \\
\hline L. N. & 72 & - & 29 & - \\
\hline V.P. & 35 & 364 & 41 & 426 \\
\hline L. V. & 42 & 712 & 51 & 865 \\
\hline I. Y. & 24 & 176 & 50 & 366 \\
\hline B. D. & 16 & 196 & 93 & 1168 \\
\hline Mean & 38.3 & 332.6 & 63.6 & 665.2 \\
\hline Normal mean & 21.9 & 476.1 & 79.6 & 1730.5 \\
\hline
\end{tabular}

duction in B cells was proportionately less than that of $\mathrm{T}$ cells. This group of acutely ill untreated patients was also compared with a group of seven patients with inactive disease receiving the equivalent of less than 15 $\mathrm{mg}$ of prednisone daily. Other than mild fatigue in two patients, and a stable rash in another two, these seven inactive patients had no symptoms of SLE. None had an abnormal urine sediment or anti-DNA antibody. As noted in Table VI, the absolute numbers of lymphocytes identified with anti-T-cell serum and EAC3 rosettes were significantly decreased in the acutely ill patients. E binding was performed in only three acutely ill patients. The difference in this marker between acutely ill and inactive patients did not reach statistical significance. No significant differences were noted in absolute number of surface Ig-bearing cells, or in the percent of lymphocytes by any of the four markers when the acutely ill untreated group was compared with the inactive group.

In view of our previous observations that lymphocytotoxins in many sera from patients with SLE had relative specificity for $T$ cells (17), an attempt was made to see if shifts in relative proportions of $T$ and $B$ cells correlated in any demonstrable way with changes in circulating lymphocytotoxins. Lymphocytotoxic antibodies against the normal panel were found in 18 of 20 patients and 30 of 42 serum samples studied. All samples with $\mathrm{T}$ cells below $65 \%$ had significant cytotoxic activity against both the normal and $\mathrm{T}$-cell panels. The mean cytotoxic index of all 42 samples was $34.6 \%$ with the normal panel, $48.8 \%$ with the $\mathrm{T}$-cell panel, and $15.3 \%$ with the CLL cell panel reflecting relative $\mathrm{T}$-cell specificity previously noted (17). No correlation was noted between percent or absolute numbers of $T$ and $B$ cells and the cytotoxic index with the normal or CLL cell panels. When the absolute number of $\mathrm{T}$ cells by anti- $\mathrm{T}$ cell serum was compared with the cytotoxic index of that sample for the T-cell panel, a trend towards an inverse correlation was noted; however, the correlation did not reach statistical significance $(r=0.29827 P<$ $0.10)$.

Previously, we noted that in many patients with RA, the sum of percent $\mathrm{T}$ and $\mathrm{B}$ cells did not add up to 100 (21). This discrepancy was explained on the basis of the appearance of a population of so-called null cells, i.e., lymphocytes that could not be identified as either $T$ or $B$ cells. When the current data on patients with SLE were examined, it was found that the mean sum of percentages of $\mathrm{T}$ and $\mathrm{B}$ cells for all determinations on the 29 patients with SLE was 101.6 $\mathrm{SD} 17.9 \%$ whereas that of 80 normal controls was $101.2 \pm \mathrm{SD} 18.8 \%$. In this manner no evidence was obtained to indicate that a significant population of null cells or double-labeled cells existed in this group of patients as a whole. In a previous study, lymphocytes labeling with both $\operatorname{IgG}$ and $\operatorname{IgM}$ or IgG and IgA were found in one SLE patient (21). At the time this study was designed this was thought to represent a rare exception to the one lymphocyte, one class of surface immunoglobulin rule. Examination of lymphocytes from patients in this current series with rhodamine-labeled anti-IgG and fluorescein-labeled antiIgA or IgM revealed however that some double labeling. did indeed occur in SLE. The mean percent of doublelabeled cells found in 10 SLE patients with $24.6 \pm 18.5$ whereas that for nine normal controls was $31.3 \pm 6.9$. The percent of lymphocytes labeling for both $\operatorname{IgG}$ and $\operatorname{IgA}$ or IgM in the SLE patients was not significantly different from that found in normal individuals. In addition, the percent of double-labeled cells did not appear to increase as the total number of Ig-bearing cells increased.

To evaluate the possibility that the increase in percent surface Ig-bearing cells might be due to coating of $T$ cells with antilymphocyte antibody, 33 SLE sera were incubated with normal human lymphocytes for $30 \mathrm{~min}$ at $37^{\circ} \mathrm{C}$, washed twice in Hanks balanced salt solution, and stained for surface Ig using a pool of equal parts anti-IgG, anti-IgM, and anti-IgA sera. The 33 sera included 16 with cytotoxic indices greater than $50 \%$ with the $\mathrm{T}$-cell panel, and representatives from blood samples showing high, normal, and low percentages of surface Ig-bearing lymphocytes. Significant elevation of the percent of cells positive for surface Ig was seen after incubation with only three sera. Two of these three had cytotoxic indices over $50 \%$ with the $\mathrm{T}$-cell panel but none were from samples in which a markedly increased percent surface Ig-bearing cells had been found. A second approach to this problem involved culture of lymphocytes from 10 patients with SLE for 48-120 h to allow for "shedding" of any adsorbed antilymphocyte anti- 
body. Cells were examined for surface Ig, EAC3 rosettes, and $\mathrm{E}$ binding at zero time and then at $24-\mathrm{h}$ intervals. The percent of cells bearing surface Ig decreased by more than $10 \%$ in four, increased in one, and did not change in five. No significant changes occurred in the percentage of cells identified by EAC3 rosettes or E binding.

Serial determinations of the susceptibility of individual SLE patients' lymphocytes to the panel of four high cytotoxic and four low cytotoxic SLE sera showed surprisingly little variability. 48 individual SLE lymphocyte samples were studied, simultaneously with normal lymphocytes. A mean of $49 \%$ of SLE lymphocytes were killed by the strongly cytotoxic sera while a mean of $54 \%$ of normal lymphocyte samples were killed. Comparable figures with the four weakly cytotoxic SLE sera were 4.9 and $3.4 \%$. The differences between the means for SLE and normals were not significant. Neither the mean percent killed by the strong and weak cytotoxic panels nor the cytotoxicity of any individual serum correlated with variations in $\mathrm{T}$ - and $\mathrm{B}$-cell percentages or acute activity in serial studies.

\section{DISCUSSION}

T-cell variation. The results recorded here indicate that the percent and absolute numbers of peripheral $T$ cells are often reduced in patients with SLE. Comparison of acutely ill untreated patients with those in remission revealed that depression in the absolute number of lymphocytes identifiable with anti-T-cell serum occurs to a greater extent in the acutely ill patients. A depression of peripheral blood $\mathrm{T}$ cells has also been recorded in studies on NZB mice afflicted with autoimmune disease $(18,19,33,34)$. In the latter instances, some degree of correlation has been shown between the diminution of peripheral blood $\mathrm{T}$ cells and the presence of lymphocytotoxic antibody. Although the hypothesis that the lymphocytotoxic antibodies found in SLE are in part responsible for the depression in $\mathrm{T}$ cells is attractive, a convincing correlation between $\mathrm{T}$ cells and the cytotoxic index of the SLE sera with the panels of normal, T-cell, or CLL lymphocytes was not noted in this study. It may be that circulating lymphocytotoxic antibodies in SLE represent residual antibody molecules of low avidity and that high affinity $\mathrm{T}$-cell-specific lymphocytotoxins have already been adsorbed to circulating $T$ cells and have cleared them to the reticuloendothelial system.

$B$-cell alterations. With respect to circulating lymphocytes bearing surface Ig, it seemed clear both from our summary data (Table II) as well as serial studies among individual patients that proportions of circulating cells bearing surface immunoglobulins were often increased and that increases frequently correlated with increased disease activity. In absolute terms the number of surface Ig-hearing lymphocytes was found to be decreased but
TABLE VI

Absolute Numbers of Lymphocytes in Active Untreated Patients Compared with Inactive Patients

\begin{tabular}{|c|c|c|c|c|}
\hline & $\begin{array}{l}\text { Number of } \\
\text { individuals }\end{array}$ & Mean & Deviation & $P$ \\
\hline \multicolumn{5}{|l|}{$\mathrm{T}$ cells } \\
\hline \multicolumn{5}{|l|}{ Anti-T-cell serum } \\
\hline Acute without $\mathbf{R}_{\mathbf{x}}$ & 7 & 665.2 & 336.1 & \multirow{2}{*}{$<0.025$} \\
\hline Inactive & 7 & 1231.6 & 473.8 & \\
\hline \multicolumn{5}{|l|}{ E binding } \\
\hline Acute without $\mathbf{R}_{\mathbf{x}}$ & 3 & 638.0 & 636.6 & \multirow{2}{*}{ NS } \\
\hline Inactive & 6 & 1102.5 & 645.6 & \\
\hline \multicolumn{5}{|l|}{ B cells } \\
\hline \multicolumn{5}{|l|}{ Anti-Ig Sera } \\
\hline Acute without $R_{x}$ & 7 & 332.6 & 203.8 & \multirow{2}{*}{ NS } \\
\hline Inactive & 7 & 465.9 & 223.6 & \\
\hline \multicolumn{5}{|l|}{$\mathrm{EAC} 3$ rosettes } \\
\hline Acute without $\mathbf{R}_{\mathbf{x}}$ & 6 & 116.8 & 52.3 & \multirow{2}{*}{$<0.01$} \\
\hline Inactive & 5 & 244.6 & 73.7 & \\
\hline
\end{tabular}

this decrease was not as great as that recorded for $T$ lymphocytes. On the other hand, the second B-cell marker, EAC3 rosette formation, showed a decrease in both percent and absolute numbers. Furthermore, comparison of acutely ill patients with those in remission revealed that the absolute number of EAC3 rosette-forming cells was decreased to a greater extent in those with the more active disease. Several explanations for this apparent discrepancy are possible. B cells may be elevated by a population of lymphocytes that lack the C3 receptor. Support for this possibility was recently provided by the demonstration of $\mathrm{B}$ lymphocytes that possess only one of these two markers in CLL (35). Another explanation is that $B$ lymphocytes are relatively increased but the C3 receptor is blocked, perhaps with adsorbed immune complexes (25) or immunoglobulins (36). Since circulating complexes are thought to play a direct role in the pathogenesis of SLE, blockage of the C3 receptor might be expected to be more notable during periods of active disease. On the other hand the proportion of $B$ lymphocytes may in fact be normal or decreased, and the percent of surface Ig-bearing lymphocytes elevated by the inclusion of $\mathrm{T}$ lymphocytes coated with antilymphocyte antibody or by double counting of $\mathrm{B}$ cells that have more than one type of immunoglobulin on their surface. Staining for multiple Ig-bearing cells in the current study indicated that the differences in percent Ig-bearing lymphocytes found between patients and controls did not appear to be due to an increase in doubly labeled cells in the patient group. A recent report by Wernet, Fotino, Thoburn, Moore, and Kunkel (36) indicates that cell surface immunoglobulin detected by immunofluorescence in some patients with SLE may be markedly reduced by incubation at $37^{\circ} \mathrm{C}$ over periods of several hours. Our studies confirm that in some patients with SLE, the percent of lymphocytes bearing surface Ig may decrease 
in culture. It was also noted that only $10 \%$ of the SLE sera tested caused an increase in the percent of detectable surface Ig-bearing cells when incubated with normal lymphocytes and that this increase did not correlate with high percentages of surface Ig-positive cells in these samples. It thus did not appear that these antibodies could be entirely responsible for the increase in percent $B$ cells. At present, however, the nature of the change in B lymphocytes in SLE must remain an open question. Evidence suggesting that the surface Ig method may be falsely increased by antilymphocyte antibody is available, but quantitative data allowing determination of the magnitude of this error needs to be strengthened. Similarly evidence exists that the EAC3 rosette method may be falsely decreased. A third independent marker for $B$ cells, which is not affected by the disease processes in SLE, would be of great help in quantifying this phenomenon.

Serial changes in proportions of lymphocytes. The results of serial studies demonstrate that dramatic fluctuations in proportions of lymphocytes identified with the four techniques used in this study may take place during the course of active SLE. A significant correlation was found between exacerbations of disease and increase in the percent of peripheral lymphocytes bearing surface Ig. These findings stand in direct contrast to the stable percentages found in normal individuals. The question as to whether the increase in the mean percent of surface Ig-positive lymphocytes and the decrease in mean percent of $\mathrm{T}$ cells, noted in the SLE patients, is due to the disease or to the drugs used in treatment is difficult to resolve from the data at hand. In some patients the increase in percent $B$ cells and decrease in $T$ cells correlated with the use of corticoid and immunosuppressive drugs. Azathioprine therapy appears to have a suppressive effect on B-cell function (37) and also on rosette-forming lymphocytes (presumably $\mathrm{T}$ cells) in normal mice (38). On the other hand, complete reversal of the $\mathrm{T}$ - and B-cell percentages was noted in one patient receiving only salicylates during an exacerbation of disease. Of seven acutely ill untreated patients, five had an increased percentage of cells staining for surface Ig whereas four had a decrease in percentage of $T$ cells. More information an acutely ill patients before treatment will be needed to clarify this problem.

A considerable body of evidence indicates that tissue damage mediated by immune complexes, as for example, DNA-anti-DNA antigen-antibody complexes in lupus glomeruli, actually constitute a prime disease effector mechanism in SLE $(39,40)$. The rise in percentage of Ig-bearing lymphocytes noted in patients with SLE in the present report might be expected if such cells were destined to be involved in humoral autoantibody produc- tion. A concomitant fall in peripheral blood $\mathrm{T}$ cells might be associated with rapid dissemination of the $T$-cell population to the actual tissue lesions themselves. At present we have no direct evidence to support such a hypothesis in SLE. Alternatively, depression of peripheral blood T-cell populations during active lupus may be associated with an acute deficiency of suppressor $\mathrm{T}$ cells $(41,42)$ thereby allowing amplified autoantibody production by $B$ lymphocytes. This amplification may be reflected in the relative increase in $B$ cells suggested in this study. It is not self evident however, that a release of autoreactive B lymphocytes would necessarily be associated with an increase in total circulating B cells detectable with these techniques. An infectious agent such as a latent virus has been postulated as the cause of SLE. Infection of $\mathrm{T}$ lymphocytes might alter their function and account for the depression of cellular immunity thought to occur in SLE (43) as well as a depression of $\mathrm{T}$-cell suppressor activity. Infection of $\mathrm{T}$ cells might also render them abnormal in such a manner as to incite the formation of T-cell-specific lymphocytotoxic antibody that in turn might lead to their destruction or alter their functional activity $(36,44)$. Considerably more data are necessary before the complete significance of changes in lymphocyte cell surface markers can be understood. It is hoped that the initial findings presented here may provide an impetus for others working in this area to focus study on the dynamics of $\mathrm{T}$ and $\mathrm{B}$ lymphocytes and their subpopulations in patients afflicted with connective tissue diseases.

\section{ACKNOWLEDGMENTS}

This work was supported in part by grants AM 13824-03 and TO1-A100343-02 from the U. S. Public Health Service and in part by a grant from the New Mexico Arthritis Foundation.

\section{REFERENCES}

1. Pernis, B., L. Forni, and L. Amante. 1970. Immunoglobulin spots on the surface of rabbit lymphocytes. J. Exp. Med. 132: 1001

2. Rabellino, E., S. Colon, H. M. Grey, and E. R. Unanue. 1971. Immunoglobulins on the surface of lymphocytes. I. Distribution and quantitation. J. Exp. Med. $133: 156$.

3. Unanue, E. R., H. M. Grey, E. Rabellino, P. Campbell, and J. Schmidtke. 1971. Immunoglobulins on the surface of lymphocytes. II. The bone marrow as the main source of lymphocytes with detectable surface-bound immunoglobulins. J. Exp. Med. 133: 1188.

4. Grey, H. M., E. Rabellino, and B. Pirofsky. 1971. Immunoglobulins on the surface of lymphocytes. IV. Distribution in hypogammaglobulinemia, cellular immune deficiency, and chronic lymphatic leukemia. $J$. Clin. Invest. 50: 2368 
5. Papmichael, M., J. C. Brown, and E. J. Holborow. 1971. Immunoglobulins on the surface of human lymphocytes. Lancet. 2 : 850.

6. Wilson, J. C., and G. J. V. Nossal. 1971. Identification of human $\mathrm{T}$ and $\mathrm{B}$ lymphocytes in normal peripheral blood and in chronic lymphocytic leukemia. Lancet. 2: 788.

7. Raff, M. C. 1969. Theta isoantigen as a marker of thymus-derived lymphocytes in mice. Nature (Lond.). 224: 378 .

8. Raff, M. C. 1971. Surface antigenic markers for distinguishing $\mathrm{T}$ and $\mathrm{B}$ lymphocytes in mice. Transplant. Rev. 6: 52 .

9. Cerottini, J. C., A. A. Nordin, and K. T. Brunner. 1970. Specific in vitro cytotoxicity of the thymus-derived lymphocytes sensitized to alloantigens. Nature (Lond.). 228: 1308.

10. Basten, A., J. F. A. P. Miller, N. L. Warner, and J. Pye. 1971. Specific inactivation of thymus-derived (T) and non-thymus-derived (B) lymphocytes by ${ }^{125} \mathrm{I}$-labelled antigen. Nat. New Biol. 231: 104.

11. Crone, M., C. Kock, and M. Simonsen. 1972. The elusive $\mathrm{T}$ cell receptor. Transplant. Rev. 10:36.

12. Mittal, K. K., R. D. Rossen, J. T. Sharp, R. D. Lidsky, and W. T. Butler. 1970. Lymphocyte cytotoxic antibodies in systemic lupus erythematosus. Nature (Lond.). 225 : 1255.

13. Terasaki, P. I., V. D. Mottironi, and E. V. Barnett. 1970. Cytotoxins in disease. Autocytotoxins in lupus. N. Engl. J. Med. $283: 724$.

14. Mittironi, V. D., and P. I. Terasaki. 1970. I. Infectious mononucleosis, rubella and measles. Histocompatibility testing. In Lymphocytotoxins in Disease. P. I. Terasaki, editor. Munksgaard, Copenhagen. 301.

15. Butler, W. T., J. T. Sharp, R. D. Rossen, M. D. Lidsky, K. K. Mittal, and D. A. Gard. 1972. Relationship of the clinical course of systemic lupus erythematosus to the presence of circulating lymphocytotoxic antibodies. Arthritis Rheum. 15: 231.

16. Williams, R. C., Jr., J. D. Emmons, and E. J. Yunis. 1971. Studies of human sera with cytotoxic activity. J. Clin. Invest. $50: 1514$.

17. Lies, R. B., R. P. Messner, and R. C. Williams, Jr. 1973. Relative T-cell specificity of lymphocytotoxins from patients with systemic lupus erythematosus. $A r$ thritis Rheum. 16: 369.

18. Shirai, T., and R. C. Mellors. 1971. Natural thymocytotoxic autoantibody and reactive antigen in New Zealand Black and other mice. Proc. Natl. Acad. Sci. U. S. A. $68: 1412$.

19. Shirai, T., T. Yoshiki, and R. C. Mellors. 1972. Thymus dependence of cells in peripheral lymphoid tissues and in the circulation sensitive to natural thymocytotoxic autoantibody in NZB mice. J. Immunol. 109: 32.

20. Williams, R. C., Jr., and J. R. DeBord, R. P. Messner, and O. J. Mellbye. 1972. Studies of T and B cells in patients with rheumatoid arthritis (RA) and systemic lupus. Arthritis Rheum. 15: 461. (Abstr.)

21. Williams, R. C., Jr., J. R. DeBord, ก. J. Mellbye, R. P. Messner, and F. D. Lindström. 1973. Studies of Tand B-lymphocytes in patients with connective tissue diseases. J. Clin. In'est. 52: 283.
22. Stobo, J. D., N. Talal, and W. E. Paul. 1972. Lymphocyte classes in New Zealand mice. II. Decreased frequency of immunoglobulin-bearing lymphocytes and increased frequency of lymphocytes lacking detectable $\theta$ or immunoglobulin determinants. J. Immunol. 109: 701.

23. Stutman, O. 1972. Lymphocyte subpopulations in NZB mice: deficit of thymus-dependent lymphocytes. J. Immunol. 109: 602 .

24. Bianco, C., R. Patrick, and V. Nussenzweig. 1970 A population of lymphocytes bearing a membrane receptor for antigen-antibody-complement complexes. I. Separation and characterization. J. Exp. Med. 132: 702.

25. Mellbye, O. J., R. P. Messner, J. R. DeBord, and R C. Williams, Jr. 1972. Immunoglobulin and receptors for C3 on lymphocytes from patients with rheumatoid arthritis. Arthritis Rheum. 15:371.

26. Fröland, S. 1972. Binding of sheep erythrocytes to human lymphocytes. A probable marker of $\mathrm{T}$ lymphocytes. Scand. J. Immunol. 1 : 269.

27. Jondal, M., G. Holm, and H. Wigzell. 1972. Surface markers on human $\mathrm{T}$ and $\mathrm{B}$ lymphocytes. I. A large population of lymphocytes forming nonimmune rosettes with sheep red blood cells. J. Exp.. Med. 136: 207.

28. Wybran, J., M. C. Carr, and H. H. Fudenberg. 1972. The human rosette-forming cell as a marker of a population of thymus-derived cells. J. Clin. Invest. 51: 2537.

29. Cohen, A. S., and J. J. Canoso. 1972. Criteria for the classification of systemic lupus erythematosus-status 1972. Arthritis Rheum. 15 : 540.

30. Böyum, A. 1968. Isolation of mononuclear cells and granulocytes from human blood. Isolation of mononuclear cells by one centrifugation, and of granulocytes by combining centrifugation and sedimentation at $1 \mathrm{~g}$. Scand. J. Lab. Clin. Invest. 21 (Suppl. 97) : 77.

31. Fröland, S., J. B. Natvig, and P. Berdal. 1971. Surfacebound immunoglobulin as a marker of B lymphocytes in man. Nature (Lond.). $234: 251$.

32. Terasaki, P. I., and J. D. McClelland. 1964. Microdroplet assay of human serum cytotoxins. Nature (Lond.). 204: 998.

33. Zatz, M. M., R. C. Mellors, and E. M. Lance. 1971. Changes on lymphoid population of aging CBA and NZB mice. Clin. Exp. Immunol. 8: 491.

34. Shirai, T., T. Yoshiki, and R. C. Mellors. 1973. Effects of natural thymocytotoxic autoantibody of NZB mice and of specifically prepared antilymphocyte serum on the tissue distribution of ${ }^{51} \mathrm{Cr}$-labeled lymphocytes. $J$. Immunol. 110: 517.

35. Ross, G. D., E. M. Rabellino, M. J. Polley, and H. M. Grey. 1973. Combined studies of complement receptor and surface immunoglobulin-bearing cells and sheep erythrocyte rosette-forming cells in normal and leukemic human lymphocytes. J. Clin. Invest. 52: 377.

36. Wernet, P., M. Fotino, R. Thoburn, A. Moore, and H. G. Kunkel. 1972. Blockage of lymphocyte surface antigens and the shedding phenomenon in systemic lupus erythematosus (SLE). Arthritis Rheum. 16: 137. (Abstr.)

37. Abdou, N. I., B. Zweiman, and S. R. Casella. 1973. Effect of azathioprine therapy on bone marrow-dependent and thymus-dependent cells in man. Clin. Exp. Immunol. $13: 55$. 
38. Bach, J. F., and M. Dardenne. 1972. Antigen recognition by $T$ lymphocytes. II. Similar effects of azathioprine, antilymphocyte serum and anti-theta serum on rosette forming lymphocytes in normal and neonatally thymectomized mice. Cell. Immunol. 3: 11.

39. Koffler, D., V. Agnello, R. Thoburn, and H. G. Kunkel. 1971. Systemic lupus erythematosus: prototype of immune complex nephritis in man. J. Exp. Med. 134: $169 \mathrm{~S}$.

40. Harbeck, R. J., E. J. Bardana, P. F. Kohler, and R. I. Carr. 1973. DNA: anti-DNA complexes: their detection in systemic lupus erythematosus sera. J. Clin. Invest. 52 : 789.
41. Allison, A. C., A. M. Denman, and R. D. Barnes. 1971. Cooperating and controlling functions of thymusderived lymphocytes in relation to autoimmunity. Lancet. 2: 135.

42. Gershon, R., and L. Kondo. 1970. Cell interactions in the induction of tolerance: the role of thymic lymphocytes. Immunology. 18: 723 .

43. Horwitz, D. A. 1972. Impaired delayed hypersensitivity in systemic lupus erythematosis. Arthritis Rheum. 15: 353.

44. Cousar, J. B., and D. A. Horwitz. 1973. Inhibition of lymphocyte activation by sera of patients with systemic lupus erythematosus. Arthritis Rheum. 16: 539. (Abstr.) 